\title{
BACE2 degradation is mediated by both the proteasome and lysosome pathways
}

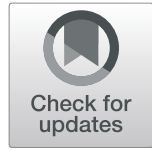

Kaixin Qiu ${ }^{1,2,3 \dagger}$, Wenping Liang ${ }^{4,5 \dagger}$, Shuai Wang ${ }^{2,3}$, Tingting Kong ${ }^{1}$, Xin Wang ${ }^{2,3}$, Chunyan Li ${ }^{1,2,3}$, Zhe Wang ${ }^{4,5}$ and Yili $\mathrm{Wu}^{2,3^{*}}$

\begin{abstract}
Background: Alzheimer's disease is the most common neurodegenerative disease in the elderly. Amyloid- $\beta$ protein $(A \beta)$ is the major component of neuritic plaques which are the hallmark of AD pathology. $\beta$-site APP cleaving enzyme 1 (BACE1) is the major $\beta$-secretase contributing to A $\beta$ generation. $\beta$-site APP-cleaving enzyme 2 (BACE2), the homolog of BACE1, might play a complex role in the pathogenesis of Alzheimer's disease as it is not only a $\theta$ secretase but also a conditional $\beta$-secretase. Dysregulation of BACE2 is observed in Alzheimer's disease. However, the regulation of BACE2 is less studied compared with BACE1, including its degradation pathways. In this study, we investigated the turnover rates and degradation pathways of BACE2 in both neuronal cells and non-neuronal cells.

Results: Both lysosomal inhibition and proteasomal inhibition cause a time- and dose-dependent increase of transiently overexpressed BACE2 in HEK293 cells. The half-life of transiently overexpressed BACE2 protein is approximately $6 \mathrm{~h}$. Moreover, the half-life of endogenous BACE2 protein is approximately $4 \mathrm{~h}$ in both HEK293 cells and mouse primary cortical neurons. Furthermore, both lysosomal inhibition and proteasomal inhibition markedly increases endogenous BACE2 in HEK293 cells and mouse primary cortical neurons.
\end{abstract}

Conclusions: This study demonstrates that BACE2 is degraded by both the proteasome and lysosome pathways in both neuronal and non-neuronal cells at endogenous level and in transient overexpression system. It indicates that BACE2 dysregulation might be mediated by the proteasomal and lysosomal impairment in Alzheimer's disease. This study advances our understanding of the regulation of BACE2 and provides a potential mechanism of its dysregulation in Alzheimer's disease.

Keywords: BACE2: half-life, Proteasome pathway: Iysosome pathway

\footnotetext{
*Correspondence: yili_wu2004@yahoo.ca; wuyili@mail.jnmc.edu.cn

${ }^{\dagger}$ Kaixin Qiu and Wenping Liang contributed equally to this work.

${ }^{2}$ Shandong Collaborative Innovation Center for Diagnosis, Treatment and Behavioral Interventions of mental disorders, Institute of Mental Health, Jining Medical University, 133 Hehua Road, Taibaihu New District, Jining 272067, Shandong, China

${ }^{3}$ Shandong Key Laboratory of Behavioral Medicine, School of Mental Health, Jining Medical University, 133 Hehua Road, Taibaihu New District, Jining, Shandong, China

Full list of author information is available at the end of the article
}

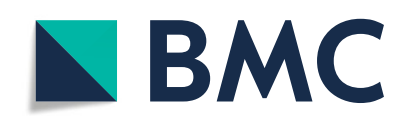

(- The Author(s). 2020 Open Access This article is licensed under a Creative Commons Attribution 4.0 International License, which permits use, sharing, adaptation, distribution and reproduction in any medium or format, as long as you give appropriate credit to the original author(s) and the source, provide a link to the Creative Commons licence, and indicate if changes were made. The images or other third party material in this article are included in the article's Creative Commons licence, unless indicated otherwise in a credit line to the material. If material is not included in the article's Creative Commons licence and your intended use is not permitted by statutory regulation or exceeds the permitted use, you will need to obtain permission directly from the copyright holder. To view a copy of this licence, visit http://creativecommons.org/licenses/by/4.0/. The Creative Commons Public Domain Dedication waiver (http://creativecommons.org/publicdomain/zero/1.0/) applies to the data made available in this article, unless otherwise stated in a credit line to the data. 


\section{Background}

Alzheimer's disease (AD) is the most common neurodegenerative disease in the elderly. Amyloid- $\beta$ protein $(A \beta)$ is the major component of neuritic plaques which are the hallmark of $\mathrm{AD}$ pathology [1]. Deposition of $\mathrm{A} \beta$ is formed from amyloid- $\beta$ precursor protein (APP) by sequential cleavage of $\beta$ - and $\gamma$-secretase [2]. $\beta$-site APP cleaving enzyme 1 (BACE1) is the major $\beta$-secretase contributing to $A \beta$ generation. $\beta$-site APP-cleaving enzyme 2 (BACE2), the homolog of BACE1, is a $\theta$-secretase, which cleaves APP at Phe20 site to yield a CTF with 80 amino acids (CTF $\theta$ or C80) contributing to the generation of a truncated $A \beta[3$, 4]. Moreover, BACE2 prevents neuronal apoptosis by cleaving a potassium channel at the surface of plasma membrane [5]. However, our recent study demonstrated that BACE2 can be converted into a $\beta$-secretase with comparable $\beta$-secretase activity to that of BACE1, implying that BACE2 could contribute to $\mathrm{A} \beta$ generation in $\mathrm{AD}$ [6].Consistently, increased BACE2 expression and activity is detected in neurons of $\mathrm{AD}$ brains [7]. Genetic data highly supports that BACE2 is associated with AD risk. For example, BACE2 haplotype associates with AD, while SNPs in BACE2 (e.g., rs2252576, rs2837990, rs7281733) predispose to early onset of $\mathrm{AD}$ in patients with Down syndrome $[8,9]$. Recently, the association between a number of SNPs in BACE2 and AD was detected in APOE $\varepsilon 4$ non-carriers, which might be mediated by altered BACE2 expression-mediated $A \beta$ generation and clearance [10]. It indicates that dysregulation of $\mathrm{BACE} 2$ might contribute to the pathogenesis $\mathrm{AD}$.

It is important to elucidate the regulation of BACE2 expression as BACE2 homeostasis is critical to maintain the physiological function and counteract the pathogenesis of $\mathrm{AD}$. In addition to the transcriptional regulation, protein degradation does play an important role in BACE2 homeostasis [11]. The ubiquitin-proteasome pathway (UPS) and the autophagy-lysosome pathway (ALP) are two major pathways for protein degradation in eukaryotic cells $[12,13]$. The impairment of the proteasome and lysomsome activity in $\mathrm{AD}$ has been reported in a number of studies, which might contribute to the dysregulation of BACE2 in AD [14]. However, the degradation of BACE2 remains elusive. To further elucidate the feature of BACE2 degradation, we investigated BACE2 degradation in both neuronal and non-neuronal cells. We found that both lysosomal inhibition and proteasomal inhibition cause the increase of transiently overexpressed BACE2 in HEK293 cells. Moreover, both lysosomal inhibition and proteasomal inhibition markedly increases endogenous BACE2 levels in HEK293 cells and mouse primary cortical neurons, indicating that BACE2 is degraded by both the proteasome pathway and lysosome pathway. This work advances our understanding of the regulation of BACE2 and provides a potential mechanism of its dysregulation in
$\mathrm{AD}$. It might provide a potential strategy for the treatment of $\mathrm{AD}$ by targeting the dysregulation of BACE2 in AD.

\section{Results}

The half-life of transiently overexpressed BACE2 is approximately $6 \mathrm{~h}$ in HEK293 cells

Cycloheximide (CHX), also called actidione, was produced from Streptomyces griseus as a protein synthesis inhibitor [15].To examine the half-life of BACE2, HEK293 cells were transfected with plasmid pBACE2mycHis. $24 \mathrm{~h}$ after transfection, cells were divided equally into six dishes. $48 \mathrm{~h}$ after transfection, the cells were treated with $100 \mu \mathrm{g} / \mathrm{mL}$ CHX to block BACE2 synthesis [16-18]. The cells were harvested at $0,2,4,8,12$ and $16 \mathrm{~h}$ time-point, respectively. Western blot analysis was performed to measure the level of remaining BACE2 protein relative to the BACE2 level at $0 \mathrm{~h}$ time-point. BACE2 protein levels were decreased to $63 \pm 6.6 \%, 58 \pm$ $7.6 \%, 45 \pm 6.7 \%, 37 \pm 4.6 \%$ and $32 \pm 4.7 \%$ at $2,4,8,12$ and $16 \mathrm{~h}$ time-point, respectively, $p<0.05$ (Fig. 1a and b). Our data showed that the half-life of transiently overexpressed BACE2 is approximately $6 \mathrm{~h}$.

\section{Lysosomal inhibition causes a time- and dose-dependent increase of transiently overexpressed BACE2 in HEK293 cells}

To explore whether the lysosome pathway is implicated in BACE2 degradation, transfected HEK293 cells were treated with $0,10,25$, or $50 \mathrm{mM}$ of the lysosomal inhibitor $\mathrm{NH}_{4} \mathrm{CL}$ for $24 \mathrm{~h}$. Western blot analysis showed that $\mathrm{NH}_{4} \mathrm{CL}$ treatment significantly increased BACE2 levels to1.35 $\pm 0.09,2.00 \pm 0.12$ and $2.40 \pm 0.12$ fold, respectively, compared to that of control cells, $p<0.05$ (Fig. 2a and $\mathrm{b})$. For the time course assay, BACE2 were treated with $25 \mathrm{mM} \mathrm{NH}_{4} \mathrm{CL}$ for $0,6,12$ and $24 \mathrm{~h}$, respectively. The levels of BACE2 were significantly increased to $1.28 \pm 0.04,1.79 \pm 0.06$ and $2.60 \pm 0.19$ fold, respectively, $p<0.05$ (Fig. 2c and d).

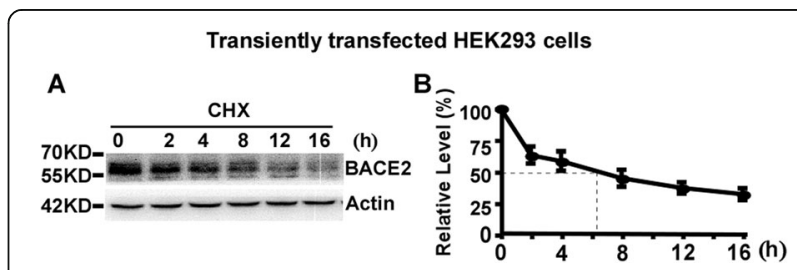

Fig. 1 The half-life of transiently overexpressed BACE2 is approximately $6 \mathrm{~h}$ in HEK293 cells. a HEK293 cells were transfected with PBACE2-mychis. $48 \mathrm{~h}$ after transfection, cells were treated with $100 \mu \mathrm{g} / \mathrm{mL}$ CHX for $0,2,4,8,12$ and $16 \mathrm{~h}$, respectively. Cell lysates were resolved by $10 \%$ SDS-PAGE. BACE2 expression was detected by using 9E10. $\beta$-actin was detected by AC-15 and served as an internal reference. $\mathbf{b}$ Quantification of BACE2 levels at each time-point. BACE2 protein levels were plotted as a percentage of the amount of BACE2 level at $0 \mathrm{~h}$. Values are mean $\pm \mathrm{SEM} ; n \geq 3$ 
Transiently transfected HEK293 cells

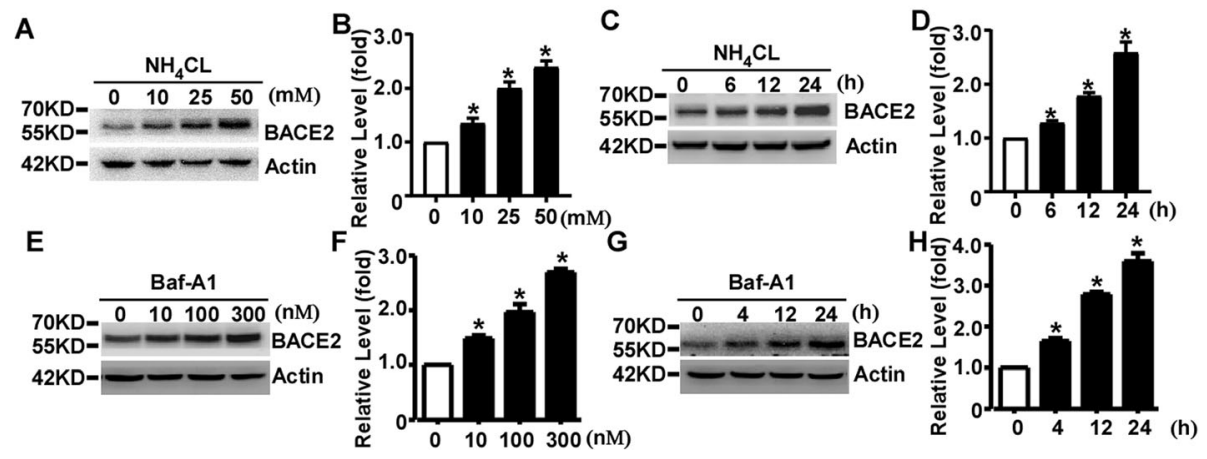

Fig. 2 Lysosomal inhibition causes a time- and dose-dependent increase of transiently overexpressed BACE2 in HEK293 cells. a HEK293 cells were transfected with pBACE2-mychis. $48 \mathrm{~h}$ after transfection, cells were treated with 0, 10, 25 or $50 \mathrm{mM}$ lysosome inhibitor $\mathrm{NH}_{4} \mathrm{CL}$ for $24 \mathrm{~h}$. b Quantification of BACE2 levels. c HEK293 cells were transfected with pBACE2-mychis. $48 \mathrm{~h}$ after transfection, cells were treated with $25 \mathrm{mM} \mathrm{NH}_{4} \mathrm{CL}$ for 0, 6, 12 or $24 \mathrm{~h}$. d Quantification of BACE2 levels. e HEK293 cells were transfected with pBACE2-mychis. $48 \mathrm{~h}$ after transfection, cells were treated with 0, 10, 100 or $300 \mathrm{nM}$ Baf-A1 for $24 \mathrm{~h}$. f Quantification of BACE2 levels. $\mathbf{g}$ HEK293 cells were transfected with pBACE2-mychis. $48 \mathrm{~h}$ after transfection, cells were treated with Baf-A1 for 0, 4, 12 or $24 \mathrm{~h}$. (h) Quantification of BACE2 levels. 9 E10 antibody was used to detect myctagged BACE2 protein. $\beta$-actin served as an internal control. Values represent mean $\pm \mathrm{SEM} ; n \geq 3,{ }^{*} P<0.05$ by one-way ANOVA followed by Tukey's test

To further confirm the effect of lysosomal inhibition on BACE2 degradation, Bafilomycin A1(Baf-A1), an inhibitor of autophagosome-lysosome fusion, was applied to BACE2 transfected cells at $0,10,100$ and $300 \mathrm{nM}$ for $24 \mathrm{~h}$, respectively. Baf-A1 treatment significantly increased BACE2 levels to1.49 $\pm 0.06,1.97 \pm 0.14$ and $2.70 \pm 0.06$ fold, respectively, compared to that of control cells, $p<0.05$ (Fig. 2e and f). For the time course assay, cells were treated with $100 \mathrm{nM}$ Baf-A1 for $0,4,12$ and $24 \mathrm{~h}$, respectively. The levels of BACE2 were significantly increased to $1.65 \pm 0.07,2.79 \pm 0.06$ and $3.60 \pm 0.19$ fold, respectively, $p<0.05$ (Fig. $2 \mathrm{~g}$ and h).Our data showed that lysosomal inhibition causes a time- and dosedependent increase of BACE2 expression, indicating that transiently overexpressed BACE2 is degraded by the lysosome pathway in HEK293 cells.

\section{Proteasomal inhibition increases transiently overexpressed BACE2 in HEK293 cells}

To explore whether the proteasome pathway is involved in BACE2 degradation, equal amount of pBACE2mycHis transfected cells were treated with proteasomal inhibitor MG-132 at the concentration of $0,10,15$ or $20 \mu \mathrm{M}$ for $12 \mathrm{~h}$. BACE2 levels were significantly increased to $6.87 \pm 0.26,7.14 \pm 0.14$ and $6.95 \pm 0.20$ fold at the dose of 10,15 and $20 \mu \mathrm{M}$, compared to that in control cells, $p<0.05$ (Fig. 3a and b). For the time course assay, cells were treated with $10 \mu \mathrm{M}$ MG-132 for $0,6,12$ and $24 \mathrm{~h}$, respectively. The levels of BACE2 were significantly increased to $2.20 \pm 0.24,5.56 \pm 0.20$ and $7.40 \pm$ 0.20 fold, respectively, $p<0.05$ (Fig. $3 c$ and d).

To further confirm the effect of proteasomal inhibition on BACE2 degradation, the proteasomal inhibitor ALLN was also applied to BACE2 transfected cells for $12 \mathrm{~h}$. ALLN treatment significantly increased BACE2 levels to $5.107 \pm 0.93,4.78 \pm 0.44$ and $5.76 \pm 0.71$ fold at the dose of 5,10 or $25 \mu \mathrm{M}$, respectively, compared to that in control cells, $p<0.05$ (Fig. 3e and f). For the time course assay, cells were treated with $10 \mu \mathrm{M}$ ALLN for $0,6,12$ and $24 \mathrm{~h}$. BACE2 levels were significantly increased to $2.69 \pm 0.20,4.72 \pm 0.32$ and $6.46 \pm 0.25$ fold, respectively, compared to that in control cells, $p<0.05$ (Fig. $3 g$ and h). It indicated that transiently overexpressed BACE2 is degraded by the proteasome pathway in HEK293 cells.

\section{The half-life of endogenous BACE2 is approximately $4 \mathrm{~h}$ in HEK293 cells}

To examine the half-life of endogenous BACE2, HEK293 cells were divided equally into four dishes. The cells were treated with $100 \mu \mathrm{g} / \mathrm{mL}$ CHX to block BACE2 synthesis [16-18]. The cells were harvested at $0,4,8$ and $12 \mathrm{~h}$ time-point, respectively. Western blot analysis was performed to measure the level of remaining BACE2 protein relative to the BACE2 level at $0 \mathrm{~h}$ time-point. BACE2 protein levels were decreased to $41 \pm 7.0 \%, 35 \pm$ $4.6 \%$ and $24 \pm 2.9 \%$ at 4,8 and $12 \mathrm{~h}$ time-point, respectively, $p<0.05$ (Fig. 4a and b). Our data showed that the half-life of endogenous BACE2 is approximately $4 \mathrm{~h}$ in HEK293 cells.

Both lysosomal inhibition and proteasomal inhibition increases the expression of endogenous BACE2 in HEK293 cells

HEK293 cells were divided equally into $6 \mathrm{~cm}$ dishes and treated with $10 \mathrm{uM}$ MG-132 for $12 \mathrm{~h}$ and $25 \mathrm{mM}$ $\mathrm{NH}_{4} \mathrm{CL}$ for $24 \mathrm{~h}$, respectively. Endogenous BACE2 levels 
Transiently transfected HEK293 cells
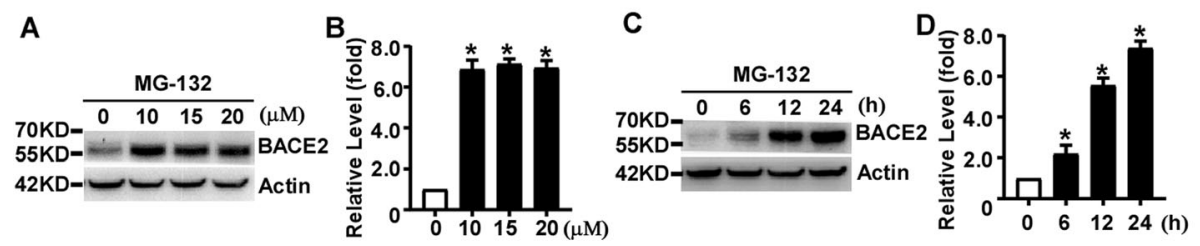

$\mathbf{E}$

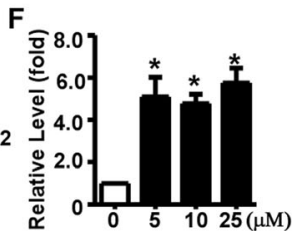

G
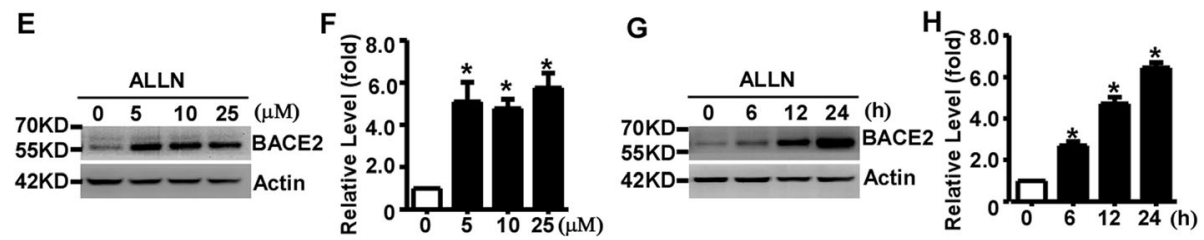

Fig. 3 Proteasomal inhibition increases transiently overexpressed BACE2 in HEK293 cells. a HEK293 cells were transfected with pBACE2-mychis. 48 h after transfection, cells were treated with 0,10,15 or $20 \mu \mathrm{M}$ proteasomal inhibitor MG-132 for $12 \mathrm{~h}$. b Quantification of BACE2 protein levels. c HEK293 cells were transfected with pBACE2-mychis. $48 \mathrm{~h}$ after transfection, cells were treated with10 $\mu \mathrm{M} \mathrm{MG}-132$ for 0, 6, 12 or $24 \mathrm{~h}$. d Quantification of BACE2 levels. e HEK293 cells were transfected with pBACE2-mychis. $48 \mathrm{~h}$ after transfection, cells were treated with 0, 5, 10 or $25 \mu \mathrm{M}$ proteasomal inhibitor ALLN for $12 \mathrm{~h}$. f Quantification of BACE2 protein levels. g HEK293 cells were transfected with pBACE2-mychis. $48 \mathrm{~h}$ after transfection, cells were treated with10 $\mu \mathrm{M}$ ALLN for $0,6,12$ or $24 \mathrm{~h}$. (h) Quantification of BACE2 levels. $9 \mathrm{E} 10$ antibody was used to detect myc-tagged BACE2 protein. $\beta$-actin served as an internal control. Values represent mean $\pm \mathrm{SEM} ; n \geq 3,{ }^{*} P<0.05$ by one-way ANOVA followed by Tukey's test

were significantly increased to $3.21 \pm 0.10$ and $6.65 \pm$ 0.20 fold by MG-132 and $\mathrm{NH}_{4} \mathrm{CL}$ treatments, respectively, compared to that in control cells, $p<0.05$ (Fig. 5a and b). Our data demonstrated that endogenous BACE2 is degraded by both the lysosome pathway and the proteasome pathway in HEK293 cells.

The half-life of endogenous BACE2 is approximately $4 \mathrm{~h}$ in primary neurons

To examine the half-life of endogenous BACE2 in primary neurons, mouse primary cortical neurons were isolated and seeded equally into five dishes. 7 days later, the cells were treated with $100 \mu \mathrm{g} / \mathrm{mL} \mathrm{CHX}$ to block BACE2 synthesis [16-18]. The cells were harvested at $0,2,4,8$ and $12 \mathrm{~h}$ time-point, respectively. Western blot analysis was performed to measure the level of remaining BACE2

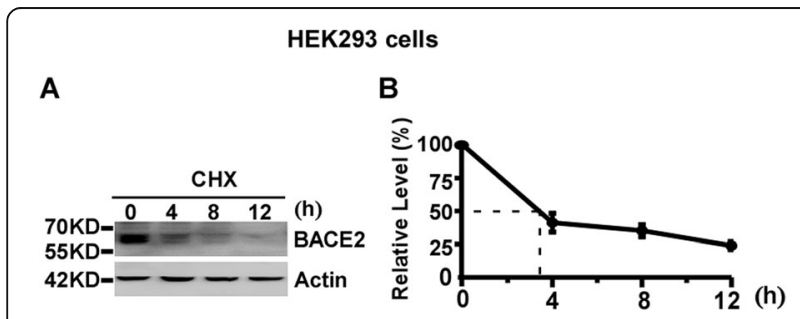

Fig. 4 The half-life of endogenous BACE2 is approximately $4 \mathrm{~h}$ in HEK293 cells. a HEK293 cells were treated with $100 \mu \mathrm{g} / \mathrm{mL}$ CHX for 0, 4,8 and $12 \mathrm{~h}$, respectively. Cell lysates were resolved by $10 \%$ SDSPAGE. BACE2 expression was detected by using anti-BACE2 antibody. $\beta$-actin was detected by AC-15 and served as an internal reference. $\mathbf{b}$ Quantification of BACE2 levels at each time-point. BACE2 protein levels were plotted as a percentage of the amount of BACE2 level at $0 h$. Values are mean $\pm \mathrm{SEM} ; n \geq 3$ protein relative to the BACE2 level at $0 \mathrm{~h}$ time-point. BACE2 protein levels were decreased to $62 \pm 2.9 \%, 45 \pm$ $2.3 \%, 34 \pm 9.6 \%$ and $28 \pm 4.4 \%$ at $2,4,8$ and $12 \mathrm{~h}$ timepoint, respectively, $p<0.05$ (Fig. $6 \mathrm{a}$ and b). Our data showed that the half-life of endogenous BACE2 is approximately $4 \mathrm{~h}$ in primary neurons.

\section{Both lysosomal inhibition and proteasomal inhibition increases the expression of endogenous BACE2 in primary neurons}

The mouse primary cortical neurons were isolated and equally seeded. 7 days later, the primary neurons were treated with $100 \mu \mathrm{g} / \mathrm{ml} \mathrm{CHL}$ and $5 \mu \mathrm{M}$ MG132, respectively. Endogenous BACE2 levels were significantly increased to $3.97 \pm 0.21$ and $8.09 \pm 0.90$ fold by MG-132

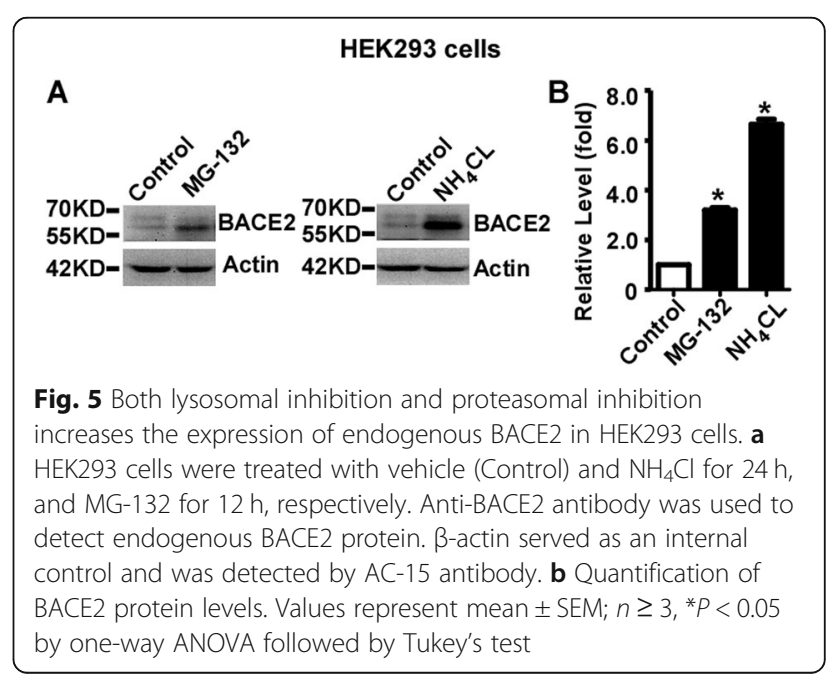




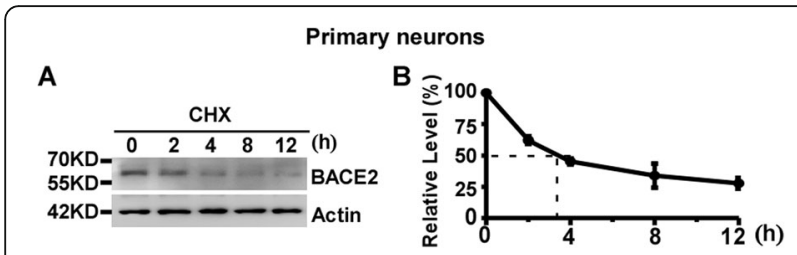

Fig. 6 The half-life of endogenous BACE2 is approximately $4 \mathrm{~h}$ in primary neurons. a Primary cortical neurons were treated with $100 \mathrm{\mu g} / \mathrm{mL}$ CHX for 0, 2, 4, 8 and $12 \mathrm{~h}$, respectively. Cell lysates were resolved by $10 \%$ SDS-PAGE. BACE2 expression was detected by using anti-BACE2 antibody. $\beta$-actin was detected by AC-15 and served as an internal reference. $\mathbf{b}$ Quantification of BACE2 levels at each time-point. BACE2 protein levels were plotted as a percentage of the amount of BACE2 level at $0 h$. Values are mean $\pm S E M ; n \geq 3$

and CHL treatments, respectively, compared to that in control cells, $p<0.05$ (Fig. 7a and b). Our data demonstrated that endogenous BACE2 is degraded by both the lysosome pathway and the proteasome pathway in mouse primary cortical neurons.

\section{Discussion}

The impairment of proteasome and lysosome function is reported in $\mathrm{AD}$, and the dysregulation of BACE2 is also observed in $\mathrm{AD}$. It suggests that impaired protein degradation function might play an important role in BACE2 dysregulation in AD by inhibiting BACE2 degradation. However, the feature of BACE2 degradation remains elusive. Thus, it is critical to elucidate the feature of BACE2 degradation. Both BACE1 and BACE2 are transmembrane proteins, and their amino acid sequences are $75 \%$ homologous. It is possible that BACE2 degradation might behave similarly to BACE1 which is degraded by both the proteasome and lysosome pathways $[3,19]$. However, our previous study showed that BACE2 is only degraded by the autophagy-lysosome

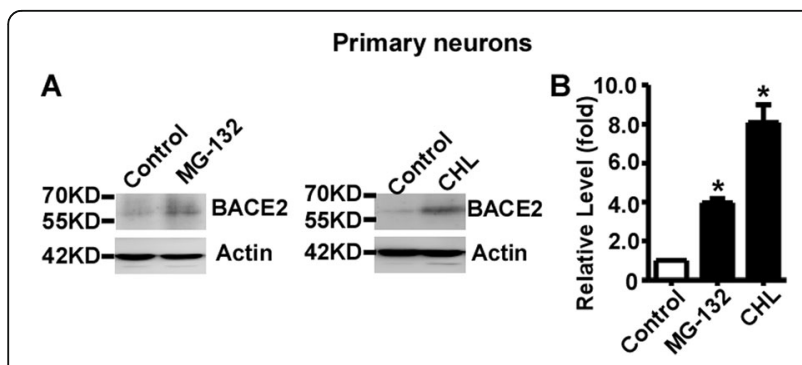

Fig. 7 Both lysosomal inhibition and proteasomal inhibition increases the expression of endogenous BACE2 in primary neurons. a Mouse primary cortical neurons were treated with vehicle (Control) and CHL for $24 \mathrm{~h}$, and MG-132 for $12 \mathrm{~h}$, respectively. AntiBACE2 antibody was used to detect endogenous BACE2 protein. $\beta$ actin served as an internal control and was detected by AC-15 antibody. b Quantification of BACE2 protein levels. Values represent mean \pm SEM; $n \geq 3,{ }^{*} P<0.05$ by one-way ANOVA followed by Tukey's test pathway in HEK293 cells stably overexpressing BACE2, but not by the proteasome pathway [18].

To further complement previous work performed in stable cells, we investigated BACE2 degradation at endogenous levels and under transient overexpression condition in both neuronal cells and non-neuronal cells. We found that both the lysosome and the proteasome pathways are implicated in the degradation of BACE2.The different conclusion drawn from the current study and the previous study might be caused by the following reasons. First, the clonal effect of stable cells might contribute to the difference as it might not represent the features of BACE2 in the population of cells. In addition, the high expression level and long-term overexpression might cause stronger stress on the cells in stable overexpression system. Moreover, long-term overexpression of BACE2 might have global effect on gene transcription including genes involved in protein degradation system, which inversely affects BACE2 degradation. For example, our previous study did show that long-term overexpression of transmembrane protein APP reduces proteasome activity by downregulating the expression of core subunits of the proteasome complex [20]. Furthermore, long-term protein overexpression might exhaust the capacity of the proteasome degradation system, resulting in proteasome impairment, thus, the proteasomal inhibitor has no effect on the proteasome-mediated BACE2 degradation in stable cells.

Our previous study showed that the half-life of stably overexpressed BACE2 is around $20 \mathrm{~h}$ [18]. In the current study, we showed that the half-life of transient overexpressed BACE2 is approximately $6 \mathrm{~h}$, while the half-life of endogenous BACE2 is approximately $4 \mathrm{~h}$. The dramatic difference between the half-life of stably overexpressed BACE2 and the half-life of transiently overexpressed BACE2 or endogenous BACE2 might be caused by the following reasons. First, the clonal effect of stable cells might contribute to the difference as it might not represent the features of BACE2 in the population of cells. Moreover, the relative long half-life of BACE2 in stable cells might be attribute to the impairment of proteasome pathway or the reduced proteasome activity as described above.

\section{Conclusions}

In conclusion, we found that BACE2 is degraded by both the proteasome and the lysosome pathways in both neuronal cells and non-neuronal cells at endogenous level or in transient overexpression system, indicating that BACE2 degradation by both the proteasome and lysosome pathways is a common feature of BACE2. Moreover, the impairment of the proteasome pathway and the lysosome pathway in AD might lead to BACE2 dysregulation in neurons, contributing to the pathogenesis of $\mathrm{AD}$ [10]. This study not only advances our 
understanding of the regulation of BACE2 but also provides a potential mechanism of its dysregulation in $\mathrm{AD}$. Moreover, it might provide a strategy for the treatment of $\mathrm{AD}$ by targeting the dysregulation of BACE2.

\section{Methods}

\section{Cell culture and transfection}

Human embryonic kidney HEK293 cells obtained from Dr. Weihong Song's lab were cultured in high-glucose DMEM containing 10\% fetal bovine serum and $1 \%$ penicillin-streptomycin. C57BL/6 mice were obtained from Cyagen Bioscience. Mouse cortical neurons were prepared from E18 embryos as described previously [6]. Briefly, the cortices of embryos were dissected out and the meninges were completely removed. The cortices were digested with papain at $37^{\circ} \mathrm{C}$ for $20 \mathrm{~min}$. Then, the papain solution was replaced with inactivation solution (MEM containing $0.6 \% \mathrm{D}$-[+]-glucose, $1 \mathrm{mM}$ pyruvate, $10 \%$ horse serum, $2.5 \%$ bovine serum albumin [BSA], and $2.5 \%$ trypsin inhibitor) and the cells were dissociated by repeatedly pipetting. The isolated cells were equally seeded on poly-D-lysine-coated dishes with Neurobasal Media (Invitrogen) containing B27 [6]. All cells were maintained at $37^{\circ} \mathrm{C}$ with $5 \% \mathrm{CO}_{2}$ in an incubator as described previously $[16,18,21]$. pBACE2-mycHis refers to pZ-BACE2mycHis in this study, which is constructed previously [22]. Transient transfection was performed by using polyetherimide (PEI) method as described previously $[23,24]$. Briefly, HEK293 cells were seeded $24 \mathrm{~h}$ prior to transfection. The regular culture medium was replaced with high-glucose DMEM without serum $1 \mathrm{~h}$ prior to transfection. $6 \mathrm{~h}$ after transfection, the medium was replaced with regular culture medium.

\section{Pharmacological treatment}

HEK293 cells were transiently transfected with pBACE2mycHis. $24 \mathrm{~h}$ after transfection, the cells were equally seeded into $6 \mathrm{~cm}$ culture dishes. $48 \mathrm{~h}$ after transfection, the cells were treated with different drugs, respectively. To measure the half-life of BACE2, $100 \mu \mathrm{g} / \mathrm{mL}$ cycloheximide (CHX) was used to treat cells as described previously $[16,18,21]$. After treatment, the cells were harvested at $0,2,4,8,12$ and $16 \mathrm{~h}$ time-point, respectively. Lysosomal inhibitor $\mathrm{NH}_{4} \mathrm{Cl}$, Bafilomycin A1(BafA1) and chloroquine (CHL) were applied to determine the involvement of lysosome pathway in BACE2 degradation, while proteasomal inhibitors $\mathrm{N}$-carbobenzoxyl-Lleucinyl-L-leucinyl-L-leucinal (MG-132) and N-AcetylL-leucyl-L-leucyl-L-norleucinal (ALLN) were applied to determine the involvement of proteasome pathway in BACE2 degradation, respectively [16-18, 25, 26]. CHX, CHL and MG-132 were added to the primary cortical neurons at DIV7. MG-132, ALLN, NH4Cl, CHL, Baf-A1 and $\mathrm{CHX}$ were purchased from Sigma.

\section{Western blotting}

Cells were lysed with RIPA-Doc buffer (Tris- $\mathrm{HCl}, 50$ $\mathrm{mM} ; \mathrm{NaCl}, 150 \mathrm{mM}$; Triton X-100, 1\%; deoxycholate, $1 \%$; and SDS, $0.1 \%$; supplemented with $1 / 100$ protease inhibitors). Cell lysates were separated by $10 \%$ Trisglycine SDS-PAGE gels and transferred to PVDF membranes. The membranes were blocked in $5 \%$ non-fat milk for $1 \mathrm{~h}$, then incubated overnight at $4{ }^{\circ} \mathrm{C}$ with antimyc (9E10), anti-BACE2 and anti- $\beta$-actin (AC-15) antibodies, respectively [18]. The membranes were washed in TBST with $0.1 \%$ Tween-20 and incubated with HRPlabeled goat anti-mouse or HRP-labelled goat anti-rabbit antibodies at room temperature for $1 \mathrm{~h}$. Anti-myc antibody $9 \mathrm{E} 10$ was obtained from Abcam. Anti-BACE2 antibody was purchased from Santa Cruz (sc-271,212). $\beta$ actin antibody AC-15, HRP-labelled goat anti-rabbit antibody and HRP-labelled goat anti-mouse antibody were obtained from ZSGB-BIO. The image was obtained by using FluorChem $\mathrm{R}$ imaging system.

\section{Statistical analysis}

The proteins expression was quantified by using ImageJ. One-way ANOVA followed by Tukey's test was used for data analysis with three or more independent experiments. $P<0.05$ was considered as a significant difference.

\section{Abbreviations}

$A \beta$ : Amyloid- $\beta$ protein; AD: Alzheimer's Disease; APP: Amyloid- $\beta$ precursor protein; BACE1: $\beta$-site APP cleaving enzyme 1; BACE2: $\beta$-site APP cleaving enzyme 2

\section{Acknowledgements}

We thank Dr. Weihong Song for providing some reagents.

\section{Authors' contributions}

YW conceived and designed the experiments; KQ, WL,SW, XW, TK, ZW and $\mathrm{CL}$ performed the experiments; KQ, WL,SW, XW and $\mathrm{YW}$ analyzed the data; $\mathrm{KQ}$ and $\mathrm{YW}$ wrote the manuscript; ZW and YL revised the manuscript. All authors have read and approved the manuscript.

\section{Funding}

This work was supported by National Natural Science Foundation of China (NSFC) Grant 81771147 and 81971019 to YW (design of the study, conduction of the experiments, analysis, interpretation of data and writing the manuscript), Grant 81870832 to ZW (conduction of the experiments, analysis, interpretation of data), Natural Science Foundation of Shandong Province of China ZR2016HM30 to YW (design of the study, conduction of the experiments, analysis, interpretation of data and writing the manuscript) and Science and Technology Bureau of Jining City Grant 2017 SMNS006 to SW(conduction of the experiments, analysis, interpretation of data and writing the manuscript).

\section{Availability of data and materials}

The datasets used and/or analyzed during the current study are available from the corresponding author on reasonable request.

Ethics approval and consent to participate Not applicable.

Consent for publication Not applicable. 


\section{Competing interests}

The authors declare that they have no competing interests.

\section{Author details}

${ }^{1}$ Cheeloo College of Medicine, Shandong University, 44 Wenhua West Road, LixiaDistrict, Jinan, Shandong, China. ${ }^{2}$ Shandong Collaborative Innovation Center for Diagnosis, Treatment and Behavioral Interventions of mental disorders, Institute of Mental Health, Jining Medical University, 133 Hehua Road, Taibaihu New District, Jining 272067, Shandong, China. ${ }^{3}$ Shandong Key Laboratory of Behavioral Medicine, School of Mental Health, Jining Medical University, 133 Hehua Road, Taibaihu New District, Jining, Shandong, China. ${ }^{4}$ The National Clinical Research Center for Geriatric Disease, Xuanwu Hospital, Capital Medical University, Beijing, China. ${ }^{5}$ Advanced Innovation Center for Human Brain Protection, Capital Medical University, Beijing, China.

Received: 6 December 2019 Accepted: 5 March 2020

Published online: 11 March 2020

\section{References}

1. Glenner GG, Wong CW. Alzheimer's disease and Down's syndrome: sharing of a unique cerebrovascular amyloid fibril protein. Biochem Biophys Res Commun. 1984;122(3):1131-5.

2. Wang X, Zhou X, Li G, Zhang Y, Wu Y, Song W. Modifications and trafficking of APP in the pathogenesis of Alzheimer's disease. Front Mol Neurosci. 2017;10:294

3. Sun X, He G, Song W. BACE2, as a novel APP theta-secretase, is not responsible for the pathogenesis of Alzheimer's disease in Down syndrome. FASEB J : Official Publication Fed Am Soc Exp Biol. 2006;20(9):1369-76.

4. Yan R. Physiological functions of the beta-site amyloid precursor protein cleaving enzyme 1 and 2. Front Mol Neurosci. 2017;10:97.

5. Liu F, Zhang Y, Liang Z, Sun Q, Liu H, Zhao J, Xu J, Zheng J, Yun Y, Yu X, et al. Cleavage of potassium channel Kv2.1 by BACE2 reduces neuronal apoptosis. Mol Psychiatry. 2018;23(7):1542-54.

6. Wang Z, Xu Q, Cai F, Liu X, Wu Y, Song W. BACE2, a conditional betasecretase, contributes to Alzheimer's disease pathogenesis. JCI Insight. 2019; 4(1):e123431.

7. Holler CJ, Webb RL, Laux AL, Beckett TL, Niedowicz DM, Ahmed RR, Liu Y, Simmons CR, Dowling AL, Spinelli A, et al. BACE2 expression increases in human neurodegenerative disease. Am J Pathol. 2012;180(1):337-50.

8. Myllykangas L, Wavrant-De Vrieze F, Polvikoski T, Notkola IL, Sulkava R, Niinisto L, Edland SD, Arepalli S, Adighibe O, Compton D, et al. Chromosome 21 BACE2 haplotype associates with Alzheimer's disease: a two-stage study. J Neurol Sci. 2005;236(1-2):17-24.

9. Mok KY, Jones EL, Hanney M, Harold D, Sims R, Williams J, Ballard C, Hardy J. Polymorphisms in BACE2 may affect the age of onset Alzheimer's dementia in Down syndrome. Neurobiol Aging. 2014;35(6):1513 e1511-5.

10. Huentelman M, De Both M, Jepsen W, Piras IS, Talboom JS, Willeman M, Reiman EM, Hardy J, Myers AJ. Common BACE2 polymorphisms are associated with altered risk for Alzheimer's disease and CSF amyloid biomarkers in APOE epsilon4 non-carriers. Sci Rep. 2019:9(1):9640.

11. Acquati F, Accarino M, Nucci C, Fumagalli $P$, Jovine L, Ottolenghi S, Taramelli R. The gene encoding DRAP (BACE2), a glycosylated transmembrane protein of the aspartic protease family, maps to the down critical region. FEBS Lett. 2000;468(1):59-64.

12. Hershko A, Ciechanover A. The ubiquitin system. Annu Rev Biochem. 1998; 67:425-79.

13. Ciechanover A. Proteolysis: from the lysosome to ubiquitin and the proteasome. Nat Rev Mol Cell Biol. 2005;6(1):79-87.

14. Zhang Y, Chen X, Zhao Y, Ponnusamy M, Liu Y. The role of ubiquitin proteasomal system and autophagy-lysosome pathway in Alzheimer's disease. Rev Neurosci. 2017;28(8):861-8.

15. Whiffen AJ. The production, assay, and antibiotic activity of actidione, an antibiotic from Streptomyces griseus. J Bacteriol. 1948;56(3):283-91.

16. Wu Y, Song W. Regulation of RCAN1 translation and its role in oxidative stress-induced apoptosis. FASEB J : Official Publication Fed Am Soc Exp Biol. 2013;27(1):208-21.

17. Liu S, Bromley-Brits K, Xia K, Mittelholtz J, Wang R, Song W. TMP21 degradation is mediated by the ubiquitin-proteasome pathway. Eur J Neurosci. 2008;28(10):1980-8.

18. Liu X, Wang Z, Wu Y, Wang J, Song W. BACE2 degradation mediated by the macroautophagy-lysosome pathway. Eur J Neurosci. 2013;37(12):1970-7.
19. Feng T, Tammineni P, Agrawal C, Jeong YY, Cai Q. Autophagy-mediated regulation of BACE1 protein trafficking and degradation. J Biol Chem. 2017; 292(5):1679-90.

20. Wu Y, Deng Y, Zhang S, Luo Y, Cai F, Zhang Z, Zhou W, Li T, Song W. Amyloid-beta precursor protein facilitates the regulator of calcineurin 1mediated apoptosis by downregulating proteasome subunit alpha type-5 and proteasome subunit beta type-7. Neurobiol Aging. 2015;36(1):169-77.

21. Sun X, Wu Y, Chen B, Zhang Z, Zhou W, Tong Y, Yuan J, Xia K, Gronemeyer $\mathrm{H}$, Flavell RA, et al. Regulator of calcineurin 1 (RCAN1) facilitates neuronal apoptosis through caspase-3 activation. J Biol Chem. 2011;286(11):9049-62.

22. Sun X, Wang Y, Qing H, Christensen MA, Liu Y, Zhou W, Tong Y, Xiao C, Huang $Y$, Zhang $S$, et al. Distinct transcriptional regulation and function of the human BACE2 and BACE1 genes. FASEB J. 2005;19(7):739-49.

23. Backliwal G, Hildinger M, Chenuet S, Dejesus M, Wurm FM. Coexpression of acidic fibroblast growth factor enhances specific productivity and antibody titers in transiently transfected HEK293 cells. New Biotechnol. 2008;25(2-3): 162-6.

24. Backliwal G, Hildinger M, Chenuet S, Wulhfard S, De Jesus M, Wurm FM. Rational vector design and multi-pathway modulation of HEK 293E cells yield recombinant antibody titers exceeding $1 \mathrm{~g} / \mathrm{l}$ by transient transfection under serum-free conditions. Nucleic Acids Res. 2008;36(15):e96.

25. Qing H, Zhou W, Christensen MA, Sun X, Tong Y, Song W. Degradation of BACE by the ubiquitin-proteasome pathway. FASEB J. 2004;18(13):1571-3.

26. Li C, Wang X, Li X, Qiu K, Jiao F, Liu Y, Kong Q, Liu Y, Wu Y. Proteasome Inhibition Activates Autophagy-Lysosome Pathway Associated With TFEB Dephosphorylation and Nuclear Translocation. Front Cell Dev Biol. 2019;7: 170.

\section{Publisher's Note}

Springer Nature remains neutral with regard to jurisdictional claims in published maps and institutional affiliations.

Ready to submit your research? Choose BMC and benefit from:

- fast, convenient online submission

- thorough peer review by experienced researchers in your field

- rapid publication on acceptance

- support for research data, including large and complex data types

- gold Open Access which fosters wider collaboration and increased citations

- maximum visibility for your research: over $100 \mathrm{M}$ website views per year

At $\mathrm{BMC}$, research is always in progress.

Learn more biomedcentral.com/submissions 